\title{
EDITORIAL
}

\section{On Launching a New English Journal, Biomedical Engineering Letters: A Letter from the President}

\author{
Do-Un Jeong \\ (The President of KOSOMBE)
}

(C) The Korean Society of Medical \& Biological Engineering and Springer 2011

On behalf of the entire membership of the Korean Sociey of Medical and Biological Engineering (KOSOMBE), I sincerely welcome all of you to the first issue of Biomedical Engineering Letters, published by KOSOMBE in collaboration with Springer-Verlag GmbH. This is an epoch-making new project for the Society and its members. We envision that this journal will become a major leading-edge publication in the field of biomedical engineering in the coming years. We hope that the subscribers and those submitting papers to the journal will share this vision with us.

First of all, I would like to express my sincere thanks to all who have contributed to the launching of this important journal in the February of 2011, especially to Prof. SangHoon Lee, editor-in-chief, and Prof. Jae Sung Lee, managing editor, as well as Prof. Sun I. Kim, immediate past President of KOSOMBE, who during his administration made a very tough decision to start this new English journal. I am also very grateful to the Springer staff for their superb support and to our printing company for their excellent job.

As of 2011, KOSOMBE is proud of its 32-year history. In 2006, it sucessfully co-hosted the World Congress on Medical Physics and Biomedical Engineering in Seoul, with approximately 3,000 participants from all over the world presenting about 2,500 papers under the theme of "Imaging the Future Medicine."

In 2010, we had a busy and productive year as we started another thirty years of history in the making, with the major new initiative on strengthening the scientific activities including the biannual congresses. And now we launch this new English journal under the theme of "Publishing the Future Medicine."

This journal with our new emblem of society on the front cover symbolizing "the collaborative development of medicine, biology, and engineering" will be a very meaningful addition to the chronicle of the biomedical engineering world. I strongly hope that the journal will encompass a wide array of disciplines within and beyond biomedical engineering and provide a creative space for facilitating scientific communication and solving health-related tasks in this aging world.

Personally, it has been a great learning experience to be a part of this launching process, and I would like to thank our Board members for having supported the launching of this journal.

Now, you are cordially invited to share your scholarly experiences with fellow researchers around the world by publishing papers in Biomedical Engineering Letters. 